\title{
DAMPAK PENERAPAN TEKNOLOGI BUDIDAYA PADI TERHADAP KESEJAHTERAAN PETANI PADI
}

\author{
Rizki Gemala Busyra \\ Dosen Pada Program Studi Agribisnis, Fakultas Pertanian Universitas Batanghari \\ J1. Slamet Riyadi-Broni, Jambi. 36122. Telp. +6274160103 \\ email : qie_bs@yahoo.com
}

\begin{abstract}
Jambi Province has implemented rice cultivation technology for food security includes land optimization, improved cropping patterns, provision of superior seeds, appropriate fertilization doses, control of Plant Disturbing Organisms and harvesting. Tanjabtim Regency has implemented rice cultivation technology including rice cultivation twice a year known as GertakTanpaDusta and Planting rice with twice harvests. This Study focused on the application of rice cultivation technology. The success of the application of rice cultivation technology in increasing both of cropping index and rice production requires an evaluation to see its impact, it is necessary to know how much is this technology in increase farmers' income by increasing the farmer welfare. This study aimed to determine the impact of the application of rice cultivation technology on the farmer welfare. This study used the model estimation method is 2SLS, by building 3 structural equations and 1 identity equation. The results showed that the application of rice cultivation technology will improve the farmer welfareas seen from the increase of land area, rice productivity and income of rice farmers.
\end{abstract}

Keywords :Cultivation Technology, Welfare, Farmer

\begin{abstract}
Abstrak
Dalam menciptakan ketahanan pangan pada komoditas padi, maka Provinsi Jambi melakukan penerapan teknologi budidaya padi yang meliputi optimalisasi lahan, perbaikan pola tanam, penyediaan benih unggul, dosis pemupukan yang tepat, pengendalian Organisme Pengganggu Tanaman (OPT) dan pemanenan. Kabupaten Tanjabtim telah menerapkan teknologi budidaya padi diantaranya penanaman padi dua kali setahun yang dikenal dengan Gertak Tanpa Dusta (Gerakan Serentak Tanam Padi Dua Kali Setahun) dan Penanaman padi dengan dua kali panen yang dikenal dengan Senam Dupa (Sekali Tanam Dua Kali Panen). Pada Penelitian ini penelitihanya berfokus pada penerapan teknologi budidaya padi berupa program Getak Tanpa Dusta. Keberhasilan penerapanteknologi budidaya padi meningkatkan indeks pertanaman dan produksi padi memerlukan evaluasi untuk melihat dampaknya, maka perlu mengetahui seberapa besar teknologi ini dalam meningkatkan pendapatan petani yang diikuti dengan peningkatan kesejahteraan petani padi. Penelitian ini bertujuan untuk mengetahui dampak penerapan teknologi budidaya padi terhadap kesejahteraan petani padi.Penelitian ini menggunakan metode estimasi model yang digunakan adalah 2 SLS, dengan membangun 3 persamaan struktural dan 1 persamaan identitas. Hasil penelitian ini memperlihatkan bahwa penerapan teknologi budidaya padi meningkatkan kesejahteraan petani yang dilihat dari peningkatan areal, produktivitas padi dan pendapatan petani padi.
\end{abstract}

Kata Kunci : Teknologi Budidaya, Kesejahteraan, Petani Padi

Diterbitkan oleh Program Studi Agribisnis Fakultas Pertanian Universitas Batanghari Jambi Halaman 53 


\section{PENDAHULUAN}

Kebijakan pangan yang telah dicanangkan pemerintahan sejak tahun 2014 dan telah tertuang dalam Nawa Cita (Sembilan Agenda) yaitu mencapai swasembada pangan dalam rangka ketahanan pangan nasional yang lebih berpihak pada peningkatan kesejahteraan petani. Kebijakan tersebut kemudian diimplementasikan Kementerian Pertanian melalui berbagai program kebijakan pembangunan pertanian, melalui optimalisasi lahan dan penambahan luas tanam, perbaikan infrastruktur dan penyediaan bantuan sarana usaha tani, serta penataan sumber daya manusia (Kementerian Pertanian, 2015).

Kebijakan pangan tersebut dilaksanakan pada seluruh provinsi di Indonesia. Dalam menciptakan ketahanan pangan pada komoditas padi, maka Provinsi Jambi melakukan penerapan teknologi budidaya padi yang meliputi optimalisasi lahan, perbaikan pola tanam, penyediaan benih unggul, dosis pemupukan yang tepat, pengendalian Organisme Pengganggu Tanaman (OPT) dan pemanenan. Kabupaten Tanjung Jabung Timur (Tanjabtim) merupakan salah kabupaten yang terdapat di Provinsi Jambi. Kabupaten Tanjabtim telah menerapkan teknologi budidaya padi diantaranya penanaman padi dua kali setahun yang dikenal dengan Gertak Tanpa Dusta (Gerakan Serentak Tanam Padi Dua Kali Setahun) dan Penanaman padi dengan dua kali panen yang dikenal dengan Senam Dupa (Sekali Tanam Dua Kali Panen) (Busyra, 2017).

Program penerapanteknologibudidaya ini diterapkan untuk meningkatkan kesejahteraan petani. Program ini merupakan upaya intensifikasi yang dilakukan Pemerintah Kabupaten (Pemkab) Tanjabtim untuk meningkatkan hasil produksi padi sawah dengan memperhitungkan kondisi lahan rawa yang ada. Saat ini sektor pertanian Tanjabtim merupakan kontributor perekonomian tertinggi setelah pertambangan dan penggalian. Dari 23.636 hektar luas lahan sawah potensial di daerah itu, baru mampu tergarap sekitar 20.572 hektar atau 87,04\%. Produksi yang dicapai sebesar 104.090 ton dengan produktivitas mencapai 3,98 ton/hektar (Dinas Pertanian Tanaman Pangan dalam Angka, 2017). Untuk mendukung program penerapanteknologibudidaya, Pemkab Tanjabtim menjamin ketersediaan dan akses petani terhadap kebutuhan pertanaman.

Keberhasilan penerapan teknologi budidaya meningkatkan indeks pertanaman dan produksi padi memerlukan evaluasi untuk melihat dampaknya, maka perlu mengetahui seberapa besar program ini dalam meningkatkan pendapatan petani yang diikuti dengan peningkatan kesejahteraan petani padi. Penggalian data kuantitatif dan kualitatif yang bersifat primer dan sekunder terhadap tenaga kerja, modal produksi, produksi, penerimaan dan pendapatan sebagai dampak dari Gertak Tanpa Dusta menjadi penting untuk memastikan bahwa program ini memang bersifat pro poor, pro growth, pro job dan pro equality menuju Tanjung Jabung Timur Sejahtera, Adil, Mandiri, Unggul, Demokratis dan Agamis (Dinas Pertanian Tanaman Pangan dan Fakultas Pertanian Universitas Batanghari, 2016).

Berdasarkan uraian di atas maka dapat dirumuskan batasan dan rumusan masalah yaitu melihat faktor-faktor yang mempengaruhi produksi dan pendapatan petani padi serta bagaimana dampak penerapan teknologi budidaya padi terhadap kesejahteraan petani padi di Kabupaten Tanjung Jabung Timur. 


\section{METODOLOGI PENELITIAN}

Penelitian dan pengambilan data dilapangan dilaksanakan pada bulan Januari sampai Mei 2019, di Kabupaten Tanjung Jabung Timur Provinsi Jambi.Jenis data yang digunakan dalam penelitian ini adalah data primer dan data sekunder. Data Primer berupa data yang diambil langsung dari petani yang terpilih sebagai sampel, pengambilan data dilakukan dengan wawancara langsung pada responden dengan menggunakan daftar pertanyaan yang terpola dan terstruktur sesuai dengan kebutuhan. Data Sekunder merupakan data tambahan yang diperoleh dari Dinas Pertanian Provinsi Jambi, Dinas Pertanian Kabupaten Tanjung Timur, Badan Pusat Statistik (BPS) Jambi dan Kabupaten Tanjung Timur, Badan Pengkajian Teknologi Pertanian (BPTP) Jambi, Dinas Perindustrian dan Perdagangan Provinsi Jambi, dan dari berbagai informasiinformasi lain seperti jurnal-jurnal pertanian, ekonomi dan hasil penelitian terdahulu serta pada beberapa situs di internet. Penelitian dilakukan dengan metode survey. Pengolahan data dilakukan dengan program komputer yaitu: SAS for Windows 9.0.

\section{Spesifikasi Model}

Model merupakan suatu penjelas dari fenomena aktual sebagai suatu sistem atau proses (Koutsoyiannis, 1977). Model ekonometrika adalah suatu pola khusus dari model aljabar, yakni suatu unsur yang bersifat stochastic yang mencakup satu atau lebih peubah pengganggu (Intriligator, 1978).

Model ekonometrika merupakan gambaran dari hubungan masing-masing variabel penjelas (explanatory variables) terhadap peubah endogen (dependent variables) khususnya yang menyangkut tanda dan besaran (magnitude and sign) dari penduga parameter sesuai dengan harapan teoritis secara apriori. Model yang baik haruslah memenuhi kriteria teori ekonomi (theoritically meaningful), kriteria statistika yang dilihat dari suatu derajat ketepatan (goodness of fit) yang dikenal dengan koefisien determinasi $\left(\mathrm{R}^{2}\right)$ serta nyata secara statistik (statistically significant) sedangkan kriteria ekonometrika menetapkan apakah suatu taksiran memiliki sifat-sifat yang dibutuhkan seperti unbiasedness, consistency, sufficiency, efficiency. Statistik $\mathrm{D}_{\mathrm{w}}$ adalah salah satu kriteria ekonometrika yang digunakan untuk menguji taksiran, yaitu menguji validitas dari asumsi autocorrelation (Koutsoyiannis, 1977).

Spesifikasi model yang dirumuskan dalam penelitian ini adalah sangat terkait dengan tujuan penelitian yaitu bagaimana dampak penerapan teknologi budidaya padi terhadap kesejahteraan petani padi. Persamaan yang disusun adaah persamaan struktural produksi dan pendapatan. Model yang dibangun adalah model ekonometrika persamaan simultan.

\section{A. Areal Padi}

Faktor-faktor yang diduga mempengaruhi areal padi di Kabupaten Tanjung Jabung Timur adalah harga padi, harga benih padi, harga pupuk, harga pestisida dan upah tenaga kerja yang digunakan. Persamaan areal padi adalah:

$\mathrm{AP}=\mathrm{a}_{0}+\mathrm{a}_{1} \mathrm{HP}+\mathrm{a}_{2} \mathrm{HBNH}+\mathrm{a}_{3} \mathrm{HPU}+\mathrm{a}_{4} \mathrm{HPEST}+\mathrm{a}_{5} \mathrm{UTK}+\mathrm{U}_{1}$ dimana: 


$\begin{array}{ll}\text { AP } & =\text { Areal Padi }(\mathrm{Ha}) \\ \mathrm{HP} & =\text { Harga Padi }(\mathrm{Rp} / \mathrm{Kg}) \\ \mathrm{HBNH} & =\text { Harga Benih }(\mathrm{Rp} / \mathrm{Kg}) \\ \mathrm{HPU} & =\text { Harga Pupuk }(\mathrm{Rp} / \mathrm{Kg}) \\ \text { HPEST } & =\text { Harga Pestisida }(\mathrm{Rp} / \text { Liter }) \\ \text { UTK } & =\text { Upah Tenaga Kerja (Rp/Orang) }\end{array}$

Tanda parameter yang diharapkan adalah:

$$
a_{1}>0 \quad a_{2}, a_{3}, a_{4}, a_{5}<0
$$

\section{B. Produktivitas Padi}

Faktor-faktor yang diduga mempengaruhi produktivtas padi di Kabupaten Tanjung Jabung Timur adalah areal padi, jumlah benih, jumlah pupuk, jumlah pestisida dan jumlah tenaga kerja yang digunakan. Persamaan produktivitas padi adalah:

$\mathrm{YP}=\mathrm{b}_{0}+\mathrm{b}_{1} \mathrm{AP}+\mathrm{b}_{2} \mathrm{JBNH}+\mathrm{b}_{3} \mathrm{JPU}+\mathrm{b}_{4} \mathrm{JPEST}+\mathrm{b}_{5} \mathrm{JTK}+\mathrm{U}_{2}$

dimana:

YP $\quad=$ Produktivitas Padi $(\mathrm{Kg} / \mathrm{Ha})$

$\mathrm{AP} \quad=$ Areal Padi $(\mathrm{Ha})$

JBNH = Jumlah Benih Yang Digunakan $(\mathrm{Kg})$

JPU = Jumlah Pupuk Yang Digunakan $(\mathrm{Kg})$

JPEST = Jumlah Pestisida Yang Digunakan (Liter)

JTK = Jumlah Tenaga Kerja (Orang)

Tanda parameter yang diharapkan adalah:

$$
\mathrm{b}_{1}, \mathrm{~b}_{2}, \mathrm{~b}_{3}, \mathrm{~b}_{4}, \mathrm{~b}_{5}>0
$$

\section{Produksi Padi}

Produksi padi didefinisikan sebagai hasil kali antara areal padi dengan produktivitasnya, yaitu:

$\mathrm{QP}=\mathrm{AP} * \mathrm{YP}$

dimana:

$\mathrm{QP}=$ Produksi Padi $(\mathrm{Kg})$

\section{Pendapatan Petani Padi}

Pendapatan petani padi di Kabupaten Tanjung Jabung Timur diduga dipengaruhi oleh produksi padi, harga padi, harga pupuk, harga pestisida dan upah tenaga kerja.

$\mathrm{I}=\mathrm{c}_{0}+\mathrm{c}_{1} \mathrm{QP}+\mathrm{c}_{2} \mathrm{HP}+\mathrm{c}_{3} \mathrm{HPU}+\mathrm{c}_{4} \mathrm{HPEST}+\mathrm{c}_{5} \mathrm{UTK}+\mathrm{U}_{3}$

dimana:

I = Pendapatan Petani $(\mathrm{Rp} / \mathrm{Ha})$

$\mathrm{QP}=$ Produksi Padi $(\mathrm{Kg})$ 


$\begin{array}{ll}\mathrm{HP} & =\text { Harga Padi }(\mathrm{Rp} / \mathrm{Kg}) \\ \mathrm{HPU} & =\text { Harga Pupuk }(\mathrm{Rp} / \mathrm{Kg}) \\ \mathrm{HPEST} & =\text { Harga Pestisida }(\mathrm{Rp} / \text { Liter }) \\ \mathrm{UTK} & =\text { Upah Tenaga Kerja }(\mathrm{Rp} / \mathrm{Ha})\end{array}$

Tanda parameter dugaan yang diharapkan:

$$
\mathrm{c}_{1}, \mathrm{c}_{2}>0 ; \quad \mathrm{c}_{3}, \mathrm{c}_{4}, \mathrm{c}_{5}<0
$$

\section{Identifikasi Model}

Identifikasi model ditentukan atas dasar "order condition" sebagai syarat keharusan dan "rank condition" sebagai syarat kecukupan. Rumusan identifikasi model persamaan struktural berdasarkan order condition adalah (Koutsoyiannis, 1977):

$(\mathrm{K}-\mathrm{M})>(\mathrm{G}-1)$

dimana:

$\mathrm{K}=$ Total variabel dalam model, yaitu endogenous variables dan predetermined variables.

$\mathrm{M}=$ Jumlah variabel endogen dan eksogen yang termasuk dalam satu persamaan tertentu dalam model, dan

$\mathrm{G}=$ Total persamaan dalam model, yaitu jumlah variabel endogen dalam model.

Jika dalam suatu persamaan model menunjukkan kondisi sebagai berikut:

$(\mathrm{K}-\mathrm{M})>(\mathrm{G}-1)=$ maka persamaan dinyatakan teridentifikasi secara berlebih (overidentified)

$(\mathrm{K}-\mathrm{M})=(\mathrm{G}-1) \quad=$ maka persamaan tersebut dinyatakan teridentifikasi secara tepat (exactly identified), dan

$(\mathrm{K}-\mathrm{M})<(\mathrm{G}-1) \quad=$ maka persamaan tersebut dinyatakan tidak teridentifikasi (unidentified).

Hasil identifikasi untuk setiap persamaan struktural haruslah exactly identified atau overidentified untuk dapat menduga parameter-parameternya. Pada penelitian ini jumlah $\mathrm{K}=13, \mathrm{M}=6$ dan $\mathrm{G}=4$, sehingga persamaan dinyatakan teridentifikasi secara berlebih (overidentified).

\section{Metode Pendugaan Model}

Dari hasil identifikasi model diketahui bahwa semua persamaan dalam model adalah overidentified. Persamaan yang demikian dapat diduga dengan menggunakan 2SLS (Two Stage Least Squares), dengan beberapa pertimbangan, yaitu penerapan 2SLS menghasilkan taksiran yang konsisten, lebih sederhana dan lebih mudah (Gujarati, 2003).

Untuk mengetahui dan menguji apakah variabel penjelas secara bersamasama berpengaruh nyata atau tidak terhadap variabel endogen, maka pada setiap persamaan digunakan uji statistik $\mathrm{F}$, dan untuk menguji apakah masing-masing variabel penjelas berpengaruh nyata atau tidak terhadap variabel endogen, maka pada setiap persamaan digunakan uji statistik t.

Selain itu dilakukan juga uji asumsi klasik yang terdiri dari beberapa uji berikut ini: 


\section{a). Uji Multikolinearitas}

Multikolinearitas menandakan bahwa terdapat hubungan linear (korelasi) yang sempurna atau pasti, diantara beberapa atau semua variabel yang menjelaskan dari model regresi (Gujarati, 2003). Model regresi yang baik seharusnya tidak terjadi hubungan linear diantara variabel independen. Menurut Ghozali (2008), bahwa untuk mendeteksi ada tidaknya multikolinearitas didalam model regresi adalah sebagai berikut :

- Menganalisis matrik korelasi variabel-variabel independen. Jika antar variabel independen ada korelasi yang cukup tinggi (umumnya di atas 0,90), maka hal ini merupakan indikasi adanya multikolinearitas.

- Multikolinearitas dapat juga dilihat dari (1) nilai tolerance dan lawannya (2) Variance Inflation Factor (VIF). Kedua ukuran ini menunjukkan setiap variabel independen manakah yang dijelaskan oleh variabel independen lainnya. Dalam pengertian sederhana setiap variabel independen menjadi variabel dependen dan diregresikan terhadap variabel independen lainnya. Tolerance mengukur variabilitas variabel independen lainnya. Jadi nilai tolerance yang rendah sama dengan nilai VIF yang tinggi (karena $\mathrm{VIF}=1 /$ nilai tolerance). Nilai cut off yang umum dipakai untuk menunjukkan adanya multikolinearitas adalah nilai tolerance $\leq 0,10$ atau sama dengan nilai $\mathrm{VIF}>10$.

\section{b). Uji Heteroskedastisitas}

Uji heteroskedastisitas digunakan untuk menguji apakah dalam suatu model regresi terjadi ketidaksamaan variance dan residual dari satu pengamatan ke pengamatan yang lain. Jika variance dari residual satu pengamatan ke pengamatan lain tetap, maka disebut homoskedastisitas dan jika berbeda maka disebut heteroskedastisitas (Ghozali, 2008). Adapun cara untuk mendeteksi ada atau tidaknya heteroskedastisitas menurut Ghozali (2008), yaitu dengan melihat grafik scatterplot antara nilai prediksi variabel dependen yaitu ZPRED dengan residualnya SRESID. Deteksi ada tidaknya heteroskedastisitas dapat dilakukan dengan melihat ada tidaknya pola tertentu pada grafik scatterplot dimana sumbu Y adalah Y yang telah diprediksi, dan sumbu $\mathrm{X}$ adalah residual ( $\mathrm{Y}$ prediksi - $\mathrm{Y}$ sesungguhnya). Adapun dasar pengambilan keputusan dilakukan dengan dasar analisis sebagai berikut :

- Jika ada pola tertentu, seperti titik-titik yang ada membentuk pola yang teratur (bergelombang, melebar, menyempit), mengindikasikan telah terjadi heteroskedastisitas.

- Jika tidak ada pola yang jelas, serta titik-titik menyebar diatas dan dibawah angka 0 pada sumbu Y, maka tidak terjadi heteroskedastisitas.

\section{c). Uji Asumsi Normalitas}

Uji asumsi normalitas digunakan untuk menguji apakah dalam suatu model regresi, variabel dependen atau keduanya mempunyai distribusi normal atau mendekati normal (Santoso, 2000). Apabila asumsi ini tidak terpenuhi, baik uji F ataupun uji-t, dan nilai estimasi nilai variabel dependen menjadi tidak valid (Utomo, 2007). Untuk mendekati normalitas pada model regresi yaitu dengan melihat penyebaran data (titik) pada sumbu diagonal dari grafik normal. Adapun dasar pengambilan keputusannya berdasarkan kriteria uji : 
- Jika data menyebar di sekitar garis diagonal dan mengikuti arah garis diagonal, maka model regresi memenuhi asumsi normalitas.

- Jika data menyebar jauh dari garis diagonal dan tidak mengikuti arah garis diagonal, maka model regresi tidak memenuhi asumsi normalitas.

\section{d). Uji Autokorelasi}

Uji autokorelasi adalah salah satu bagian dari uji asumsi klasik dimana suatu persamaan regresi dikatakan telah memenuhi asumsi tidak terjadi autokorelasi dengan menggunakan uji Durbin Watson. Menurut Santoso (2000) bahwa tujuan uji autokorelasi adalah untuk mengetahui apakah dalam suatu model regersi linear ada korelasi antara kesalahan pengganggu dengan kesalahan sebelumnya. Apabila hal ini terjadi maka terdapat masakah autokorelasi. Adapun kritik pengujiannya adalah jika $d u<d<4-d u$ maka Ho ditolak yang berarti tidak ada autokorelasi baik positif maupun negatif. Untuk mengetahui ketepatan model regresi sampel dalam menaksir nilai aktualnya dapat diukur dari goodness of fit- nya. Goodness of fit dalam model regresi dapat diukur dari nilai koefisien determinasi, nilai statistik F, dan uji statistik t.

\section{Validasi Model}

Untuk mengetahui apakah model cukup valid untuk membuat suatu simulasi kebijakan pertanian dan faktor eksternal dan peramalan, maka perlu dilakukan suatu validasi model, dengan tujuan untuk menganalisis sejauhmana model tersebut dapat mewakili dunia nyata.

Dalam penelitian ini, kriteria statistik untuk validasi nilai pendugaan model ekonometrika yang digunakan adalah Root Means Square Error (RMSE), Root Means Percent Square Error (RMSPE) dan Theil's Inequality Coefficient (U) (Pindyck and Rubinfield, 1991). Kriteria - kriteria dirumuskan sebagai berikut:

$$
\begin{aligned}
& R M S E=\sqrt{\frac{1}{n} \sum_{t=1}^{n}\left(Y_{t}^{s}-Y_{t}^{a}\right)^{2}} \\
& R M S P E=\sqrt{\frac{1}{n} \sum_{t=1}^{n}\left(\frac{Y_{t}^{S}-Y_{t}^{a}}{Y_{t}^{a}}\right)^{2}} \\
& U=\frac{\sqrt{\frac{1}{n} \sum_{t=1}^{n}\left(Y_{t}^{S}-Y_{t}^{a}\right)^{2}}}{\sqrt{\frac{1}{n} \sum_{t=1}^{n}\left(Y_{t}^{S}\right)^{2}}+\sqrt{\frac{1}{n} \sum_{t=1}^{n}\left(Y_{t}^{a}\right)^{0.5}}}
\end{aligned}
$$

dimana:

$$
\begin{aligned}
& Y_{t}^{s}=\text { nilai hasil simulasi dasar dari variabel observasi } \\
& Y_{t}^{a}=\text { nilai aktual variabel observasi } \\
& n=\text { jumlah periode observasi }
\end{aligned}
$$

Statistik RMSPE digunakan untuk mengukur seberapa jauh nilai-nilai peubah endogen hasil pendugaan menyimpang dari alur nilai-nilai aktualnya dalam ukuran relatif (persen), atau seberapa dekat nilai dugaan itu mengikuti perkembangan nilai aktualnya. 
Sedangkan nilai statistik U bermanfaat untuk mengetahui kemampuan model untuk analisis simulasi peramalan. Nilai koefisien Theil (U) berkisar antara 1 dan 0 . Jika $U=0$ maka pendugaan model sempurna, jika $U=1$ maka pendugaan model naif.

Untuk melihat keeratan arah (slope) antara aktual dengan hasil yang disimulasi dilihat dari nilai koefisien determinasinya $\left(\mathrm{R}^{2}\right)$. Pada dasarnya makin kecil nilai RMSPE dan U-Theil's dan makin besar nilai $\mathrm{R}^{2}$, maka pendugaan model semakin baik.

\section{Simulasi Model}

Setelah divalidasi, prosedur berikutnya adalah simulasi model. Analisis simulasi digunakan untuk menjelaskan dampak penerapan teknologi budidaya padi terhadap kesejahteraan petani padi. Analisis simulasi diterapkan pada periode Januari 2015 - Januari 2019, karena teknologi budidaya baru dilaksanakan sejak tahun 2015 dan data lebih lengkap dan terjamin.

Analisis ini mencakup periode yang sudah lampau, sehingga simulasi ini dinamakan simulasi historis. Dengan demikian beberapa skenario simulasi alternatif dampak penerapan teknologi budidaya terhadap kesejahteraan petani padi, yaitu:

1. Peningkatan luas areal padi sebesar 6 persen.

Simulasi ini dilakukan berdasarkan data perkembangan areal padi di Kabupaten Tanjung Timur, dimana peningkatan lahan tertinggi adalah sebesar 6 persen dalam 3 tahun terakhir.

2. Peningkatan jumlah bantuanbenihsebesar 5 persen.

3. Peningkatan jumlah bantuan pupuk sebesar 5 persen.

4. Peningkatan harga padi sebesar 10 persen. 


\section{HASIL DAN PEMBAHASAN}

\section{Gambaran Umum Hasil Estimasi Model}

Model penerapan teknologi budidaya pada komoditas padi di Kabupaten Tanjung Jabung Timur dalam penelitian ini merupakan model simultan dinamis yang dibangun dari 4 persamaan, terdiri dari 3 persamaan perilaku dan 1 persamaan identitas. Model yang dibangun menggambarkan adanya keterkaitan antara penerapan teknologi budidaya pada komoditas padi dengan kesejahteraan petani padi. Model tersebut telah melalui beberapa tahapan respesifikasi model. Data yang digunakan adalah data mengenaiproduksi, produktivitas, biaya dan pendapatan pada komoditas padi Kabupaten Tanjung Jabung Timur yang disusun sebagai pooled data, mulai bulan September 2018 sampai bulan Mei 2019.

Secara umum hasil estimasi model pada umumnya telah sesuai dengan pertimbangan-pertimbangan ekonomi dan statistik sehingga model dimaksud mampu menggambarkan fenomena-fenomena yang berkaitan dengan komoditas padi dan pendapatan petani di dunia nyata. Seluruh persamaan perilaku memiliki koefisien determinasi $\left(\mathrm{R}^{2}\right)$ di atas 0.82 (mencapai 0.86). Kondisi ini menunjukkan bahwa secara umum kemampuan peubah-peubah penjelas yang ada pada persamaan perilaku mampu menjelaskan dengan baik peubah endogennya.

Nilai statistik F dalam model umumnya nyata secara statistik, yaitu berkisar antara 84.65 sampai 131.98, yang berarti variasi peubah-peubah penjelas dalam setiap persamaan perilaku secara bersama-sama mampu menjelaskan dengan baik variasi peubah endogennya. Sedangkan untuk variabel penjelas secara individual terdapat beberapa variabel penjelas yang tidak berepengaruh nyata terhadap peubah endogen. Hasil penelitian menunjukkan adanya nilai $t$ statistik yang beragam tingkat signifikansinya.

Pada penelitian ini masalah autokorelasi dapat dideteksi dengan menggunakan statistik Durbin Watson (DW). Nilai statistik Durbin Watson persamaan struktural dalam model berkisar antara 1.803474 sampai 1.964689 . Hal ini mengindikasikan tidakada persamaan yang mengandung masalah autokorelasi (Pindyck and Rubinfeld,1991).

\section{Pembahasan Model Estimasi}

Setelah dicoba beberapa alternatif spesifikasi model maka akhirnya diperoleh model penerapan teknologi budidaya dan pendapatan petani pada komoditas padi di Kabupaten Tanjung Jabung Timur terdiri dari 3 persamaan struktural sebagai berikut:

\section{A. Areal Padi}

Pada Tabel 1 menunjukkan bahwa peubah penjelas pada persamaan areal padi mampu menjelaskan secara baik $(82,598)$ keragaman perkembangan areal padi. Areal padi berhubungan positif dengan harga padi di tingkat petani. Sementara itu areal padi berhubungan negatif dengan harga benih, harga pupuk, harga pestisida dan upah tenaga kerja. Semua tanda ekonomi pada persamaan ini telah sesuai dengan harapan. Perilaku areal padi dipengaruhi secara nyata pada taraf 5 persen oleh harga padi, harga benih, dan upah tenaga kerja. Perubahan harga padi sebesar satu rupiah akan mengakibatkan perubahan areal padi sebesar 0.139503(sejalan dengan penelitian Busyra, 2016), perubahan areal padi lebih kecil dibandingkan dengan perubahan harga padi disebabkan petani belum tentu akan memperluas areal padinya ketika harga padi meningkat, karena keuntungan yang diperoleh 
petani dari peningkatan harga padi digunakan untuk pembelian input yang dibutuhkan, atau bisa digunakan petani untuk pembelian kebutuhan hidupnya.

Perubahan harga benih sebesar satu rupiah mengakibatkan perubahan areal padi sebesar-8.16E-6. Hal ini disebabkan benih padi merupakan input produksi dalam produksi padi, apabila harga benih meningkat maka petani akan mengurangi jumlah pembeliannya yang mengakibatkan tidak seluruh areal padi ditanami, sehingga luas areal yang ditanami menjadi berkurang.

Besarnya perubahan areal padi sebagai akibat perubahan tingkat upah sebesar 1 rupiah adalah sebesar-1.17E-7(sejalan dengan penelitian Kusumaningrum, 2008). Di daerah penelitian, dalam mengolahlahannya petani masih menggunakan tenaga kerja dari luar keluarga, apabila upah tenaga kerja meningkat maka petani akan mengurangi penggunaan jumlah tenaga kerja dalam mengolah lahan. Hal ini mengakibatkan luas lahan yang diolah menjadi berkurang.

Tabel 1. Hasil Estimasi Persamaan Areal Padi

\begin{tabular}{lrrl}
\hline \multicolumn{1}{c}{ Variabel } & $\begin{array}{c}\text { Parameter } \\
\text { Estimasi }\end{array}$ & Prob $>|\mathrm{t}|$ & Label \\
\hline Intercept & 0.721319 & 0.0562 & Intercept \\
HP & 0.139503 & 0.0446 & Harga Padi di tingkat petani $(\mathrm{Rp} / \mathrm{Kg})$ \\
HBNH & $-8.16 \mathrm{E}-6$ & $<.0001$ & Harga Benih $(\mathrm{Rp} / \mathrm{Kg})$ \\
HPU & $-6.8 \mathrm{E}-7$ & 0.1331 & Harga Pupuk $(\mathrm{Rp} / \mathrm{Kg})$ \\
HPEST & $-7.64 \mathrm{E}-7$ & 0.1102 & Harga Pestisida (Rp/Kg) \\
UTK & $-1.17 \mathrm{E}-7$ & 0.0290 & Upah Tenaga Kerja (Rp/orang) \\
\hline R-Square & 0.82598 & & Dw \\
F-hit & 84.65 & & 1.945775 \\
\hline
\end{tabular}

Sumber: Data Olahan Primer, 2019

\section{B. Produktivitas Padi}

Pada Tabel 2 menunjukkan bahwa peubah penjelas pada persamaan produktivitas padi mampu menjelaskan secara baik $(86,864)$ keragaman perkembangan produktivitas padi. Hasil pada Tabel 2 menunjukkan bahwa produktivitas padi di Tanjung Jabung Timur berhubungan positif dengan areal padi, jumlah benih yang digunakan, jumlah pupuk, jumlah pestisida, dan jumlah tenaga kerja.Persamaan produktivitas padi dipengaruhi secara nyata pada taraf nyata 5 persen oleh areal padi, jumlah benih yang digunakan, jumlah pupuk, dan jumlah tenaga kerja.

Perubahan areal padi sebesar $1 \mathrm{Ha}$ akan mengakibatkan perubahan produktivitas sebesar 548.893. Hal ini dikarenakan penambahan areal padi akan menyebabkan peningkatan produksi padi sehingga mengakibatkan produktivitas juga ikut meningkat (sesuai dengan penelitian Busyra, 2016)

Perubahan jumlah benih yang digunakan sebesar 1 kilogram akan mengakibatkan peningkatan produktivitas sebesar $9.15654 \mathrm{~kg} / \mathrm{ha}$. Hal ini dikarenakan benih merupakan input produksi, sehingga bila jumlah penggunaan benih ditingkatkan maka produksi juga meningkat dan juga akan meningkatkan produktivitas padi. petani. Perubahan jumlah pupuk sebesar 1 kilogram akan meningkatkan produktivitas padi sebesar $4.55034 \mathrm{~kg} / \mathrm{ha}$. Hal ini dikarenakan bila 
pupuk yang digunakan petani terus ditingkatkan sampai sesuai dengan dosis yang dianjurkan maka produksi padi akan meningkat yang juga diikuti dengan peningkatan produktivitas.

Perubahan jumlah tenaga kerja 1 orang akan mengakibatkan perubahan produktivitas padi sebesar 13.1280. Penyebabnya adalah petani padi menggunakan tenaga kerja dari luar keluarga, maka penambahan jumlah tenagakerja yang digunakan akan meningkatkan produksi dan produktivitas padi.

Tabel 2. Hasil Estimasi Persamaan Produktivitas Padi

\begin{tabular}{lccl}
\hline Variabel & Parameter Estimasi & Prob $>|t|$ & \multicolumn{1}{c}{ Label } \\
\hline Intercept & 6796.985 & $<.0001$ & Intercept \\
AP & 548.893 & 0.0075 & Areal Padi (Ha) \\
JBNH & 9.15654 & 0.0306 & Jumlah Benih (Kg) \\
JPU & 4.55034 & 0.0073 & Jumlah pupuk (Kg) \\
JPEST & 87.94917 & 0.1827 & Jumlah pestisida (liter) \\
JTK & 13.1280 & 0.0371 & Jumlah Tenaga Kerja (orang) \\
\hline R-Square & 0.86864 & & Dw 1.964689 \\
F-hit & 124.85 & & \\
\hline
\end{tabular}

Sumber: Data Olahan Primer, 2019

\section{Pendapatan Petani Padi}

Hasil pada Tabel 3 menunjukkan bahwa peubah penjelas pada persamaan pendapatan petanipadi mampu menjelaskan secara baik yaitu sebesar 83.018. Pendapatan petani padi berhubungan positif dengan produksi padi dan harga padi. Serta berhubungan negative dengan harga pupuk, harga pestisida dan upah tenaga kerja. Persamaan pendapatan petani dipengaruhi secara nyata pada taraf nyata 5 persen oleh produksi padi, harga padi, hargapupuk dan upah tenaga kerja.

Perubahan produksi padi sebesar $1 \mathrm{~kg}$ akan mengakibatkan perubahan pendapatan petani sebesar 12.00285. Hal ini dikarenakan penambahan produksi padi akan meningkatkan jumlah penjualan padi sehingga menyebabkan pendapatan petanipun meningkat.

Perubahan harga padi sebesar Rp. 1,-/kilogram akan mengakibatkan perubahan pendapatan petani sebesar 4198990. Hal ini dikarenakan semakin tinggi harga padi maka petani akan mendapatkan keuntungan lebih banyak sehingga mengakibatkan pendapatan petani meningkat.

Perubahan harga pupuk sebesar Rp. 1,-/kg akan mengakibatkan perubahan pendapatan petani sebesar -3.10554. Karena pupuk merupakan salah satu faktor produksi dalam usahatani padi, semakin besar biaya yang dikeluarkan untuk membeli pupuk akan mengakibatkan semakin kecilnya pendapatan yang diterima petani.

Perubahan upah tenaga kerja sebesar Rp. 1,-/orang akan mengakibatkan perubahan pendapatan petani sebesar -0.07160 . Penyebabnya adalah semakin mahal upah tenaga kerja maka semakin besar biaya yang dikeluarkan petani, sehingga pendapatan petani akan menurun.

Tabel 3. Hasil Estimasi Persamaan Pendapatan Petani Padi 


\begin{tabular}{lccl}
\hline Variabel & Parameter Estimasi & Prob $>|\mathrm{t}|$ & \multicolumn{1}{c}{ Label } \\
\hline Intercept & 5613428 & 0.0003 & Intercept \\
QP & 12.00285 & 0.0002 & ProduksiPadi $(\mathrm{Kg})$ \\
HP & 4198990 & 0.0180 & Harga Padi $(\mathrm{Rp} / \mathrm{Kg})$ \\
HPU & -3.10554 & 0.0200 & Harga Pupuk (Rp/Kg) \\
HPEST & -0.95936 & 0.1086 & Harga Pestisida (Rp/Liter) \\
UTK & -0.07160 & 0.0247 & Upah Tenaga Kerja (Rp/Orang) \\
\hline R-Square & 0.83018 & & Dw 1.803474 \\
F-hit & 131.98 & &
\end{tabular}

\section{Evaluasi Daya Prediksi Model}

Validasi model dilakukan secara historis untuk bulan September 2018 sampai bulan Mei 2019. Ada 4 peubah endogen yang divalidasi, hasil validasi model menunjukkan bahwa sebagian besar variabel endogen memiliki nilai ratarata RMSPE sebesar 3.87 persen dan U-Theil sebesar 0.19. Dari kondisi tersebut dapat disimpulkan bahwa sebagian besar persamaan di dalam model memiliki daya prediksi yang baik, dan cukup valid untuk melakukan simulasi.

\section{DampakPenerapanTeknologiBudidayaPadiTerhadapKesejahteraanPetani Padi}

Evaluasi dampak penerapan teknologi Budidaya Padi terhadap kesejahteraan petani padi, yaitu peningkatan areal padi, peningkatan subsidi benih, dan pupuk, peningkatan produksi akibat penerapan teknologi dan peningkatan harga padi. Evaluasi dilakukan terhadap 4 skenario simulasi historis. Berikut ini dikemukakan hasil simulasi pada masing-masing skenario.

\section{a. Peningkatan Areal Padi}

Dari Tabel 4 dapat dijelaskan bahwa peningkatan areal padi sebesar 6 persen menyebabkan peningkatan produktivitas padi sebesar 2.5634 persen. Hal ini sesuai dengan hasil estimasi dimana peningkatan areal padi berpengaruh nyata dalam meningkatkan produktivitas padi. Selain itu peningkatan areal padi juga akan meningkatkan produksi padi sebesar 3.4710 persen. Peningkatan produksi padi diikuti oleh peningkatan pendapatan petani padi sebesar 5.3267 persen. Hal ini sejalan dengan hasil estimasi dimana produksi padi berpengaruh nyata terhadap pendapatan petani padi.

Tabel 4. Dampak Peningkatan Areal Padi sebesar 6 persen terhadap Kesejahteraan Petani Padi

\begin{tabular}{clrrr}
\hline No & Variabel Endogen & Nilai Dasar & Nilai Simulasi & Perubahan $(\%)$ \\
\hline $\mathbf{1}$ & Areal Padi & $\mathbf{3 4 2 6 . 9}$ & $\mathbf{3 6 3 2 . 5}$ & $\mathbf{6 . 0 0 0 0}$ \\
2 & Produktivitas Padi & 5.472 & 5.612 & 2.5634 \\
3 & Produksi Padi & 8794 & 9099.24 & 3.4710 \\
4 & PendapatanPetaniPadi & 789345 & 831391.04 & 5.3267 \\
\hline
\end{tabular}

Diterbitkan oleh Program Studi Agribisnis Fakultas Pertanian Universitas Batanghari Jambi Halaman 64 
Sumber: Data Olahan Primer, 2019

\section{b. Peningkatan Jumlah Bantuan Benih}

Tabel 5 memperlihatkan bahwa peningkatan pemberian subsidi benih sebesar 5 persen akan menyebabkan produktivitas padi meningkat sebesar 15.4951 persen. Hal ini sesuai dengan hasil estimasi dimana peningkatan subsidi benih berpengaruh nyata dalam meningkatkan produktivitas padi.

Tabel 5. Dampak Peningkatan Subsidi Benihsebesar 5 persen terhadap Pendapatan Petani Padi

\begin{tabular}{clrrr}
\hline No & Variabel Endogen & Nilai Dasar & Nilai Simulasi & Perubahan $(\%)$ \\
\hline 1 & Areal Padi & 3426.9 & 3732.19 & 8.9087 \\
2 & Produktivitas Padi & 5.472 & 6.3198 & 15.4951 \\
3 & Produksi Padi & 8794 & 11346.17 & 29.0218 \\
4 & Pendapatan Petani Padi & 789345 & 1057620.47 & 33.9871 \\
\hline
\end{tabular}

Selain itu peningkatan produktivitas padi juga disebabkan oleh peningkatan areal padi sebesar 8.9087 persen yang diikuti oleh peningkatan produksi padi sebesar 29.0218 persen. Hal ini juga sesuai dengan hasil estimasi, dimana peningkatan areal padi berpengaruh nyata terhadap peningkatan produktivitas padi. Peningkatan Produksi padi akan mempengaruhi peningkatan pendapatan petani sebesar 33.9871 persen.

\section{c. Peningkatan Jumlah Bantuan Pupuk}

Pada Tabel 6 dapat dilihat bahwa peningkatan subsidi pupuk sebesar 5 persen akan meningkatkan produktivitas sebesar 21.8748 persen. Hal ini sesuai dengan hasil estimasi dimana peningkatan subsidi pupuk berpengaruh nyata dalam meningkatkan produktivitas padi.

Tabel 6. Dampak Peningkatan Subsidi Pupuk sebesar 5 persen terhadap Pendapatan Petani Padi

\begin{tabular}{clrrr}
\hline No & Variabel Endogen & Nilai Dasar & Nilai Simulasi & Perubahan $(\%)$ \\
\hline 1 & Areal Padi & 3426.9 & 3457.03 & 0.8792 \\
2 & Produktivitas Padi & 5.472 & 6.668 & 21.8748 \\
3 & Produksi Padi & 8794 & 11875.91 & 35.0456 \\
4 & Pendapatan Petani Padi & 789345 & 1110486.06 & 40.6845 \\
\hline Sumbr:
\end{tabular}

Sumber: Data Olahan Primer, 2019

Selain itu peningkatan produktivitas padi juga disebabkan oleh peningkatan areal padi sebesar 0.8792 persen yang diikuti oleh peningkatan produksi padi sebesar 35.0456 persen. Hal ini juga sesuai dengan hasil estimasi, dimana peningkatan areal padi berpengaruh nyata terhadap peningkatan produktivitas padi. Peningkatan Produksi Padi akan mempengaruhi peningkatan pendapatan petani padi sebesar 40.6845 persen.

\section{d. Peningkatan HargaPadi}

Pada Tabel 7 dapat dilihat bahwa peningkatan harga padi sebesar 10 persen akan meningkatkan areal sebesar 15.7453 persen. Hal ini sesuai dengan hasil 
estimasi dimana peningkatan harga padi berpengaruh nyata dalam meningkatkan areal padi.

Tabel 7. Dampak Peningkatan Harga Padi sebesar 10 persen terhadap Pendapatan Petani Padi

\begin{tabular}{clrrr}
\hline No & Variabel Endogen & Nilai Dasar & Nilai Simulasi & Perubahan $(\%)$ \\
\hline 1 & Areal Padi & 3426.9 & 3966,5 & 15.7453 \\
2 & Produktivitas Padi & 5.472 & 6.491 & 18.6289 \\
3 & Produksi Padi & 8794 & 11227.77 & 27.6754 \\
4 & Pendapatan Petani Padi & 789345 & 1175470.47 & 48.9172 \\
\hline Sumber: Data Olahan Primer, 2019 & & &
\end{tabular}

Selain itu peningkatan areal padi juga menyebabkan peningkatan produksi dan produktivitas padi, masing-masingnya sebesar 27.6754 dan 18.6289. Peningkatan produksi padi akan mempengaruhi peningkatan pendapatan petani padi sebesar 48.9172 persen. Hal ini juga sesuai dengan hasil estimasi, dimana peningkatan harga padi berpengaruh nyata terhadap peningkatan pendapatan petani padi.

\section{KESIMPULAN}

Berdasarkan hasil penelitian yang telah dikemukakan di atas, maka dapat ditarik beberapa kesimpulan sebagai berikut:

1. Faktor-faktor yang mempengaruhi peningkatan areal padi adalah harga padi, harga benih, dan upah tenaga kerja. Produktivitas padi dipengaruhi secara signifikan oleh areal padi, jumlah benih yang digunakan, jumlah pupuk, dan jumlah tenaga kerja.. Pendapatan petani padi dipengaruhi secara nyata oleh produksi padi, harga padi, harga pupuk dan upah tenaga kerja.

2. Penerapan teknologi yang dilakukan (dalam hal ini adalah peningkatan areal sawah dengan pembukaan lahan sawah baru, subsidi benih varietas unggul, pemakaian pupuk dengan dosis yang tepat dengan subsidi pupuk) kepada komoditas padi akan berdampak kepada peningkatan kesejahteraan petani padi (yang menggunakan tingkat pendapatan sebagai salah satu indicator kesejahteraan petani) .

\section{DAFTAR PUSTAKA}

A.T. Mosher. 1987. Menggerakkan Dan Membangun Pertanian. Yasaguna. Jakarta.

Badan Pusat Statistik Provinsi Jambi. 2018. Jambi Dalam Angka. Badan Pusat Statistik Provinsi Jambi. Jambi.

BP2TP. 2008. Teknologi Budidaya Padi. Litbang Departemen Pertanian. Bogor.

Busyra, R.G. 2016. Dampak Program Upaya Khusus (UPSUS) Padi Jagung Kedelai (Pajale) Pada Komoditas Padi Terhadap Perekonomian Kabupaten Tanjung Jabung Timur. Jurnal Media Agribisnis (MeA) Vol.1 No.1 : 1227.

Busyra, R.G. 2017. Perbandingan Pendapatan Petani Padi Sistem Senam Dupa (Sekali Tanam Dua Kali Panen) Dengan Petani Padi Sistem Konvensional 
Di Kecamatan Berbak Kabupaten Tanjabtim. Jurnal Media Agribisnis (MeA), ISSN No. 2541-6898 Vol. 1 No. 1 Oktober 2017.

Dinas Pertanian Kabupaten Tanjung Jabung Timur. 2017. Dinas Pertanian Tanaman Pangan Dalam Angka. Dinas Pertanian Kabupaten Tanjung Jabung Timur. Kabupaten Tanjung Jabung Timur.

Ghozali, I. 2008. Aplikasi Analisis Multivariate Dengan Program SPSS. Undip Press. Semarang.

Gujarati, D. 2003. Ekonometrika Dasar. Terjemahan. Erlangga. Jakarta.

Hutagalung, M. 2007. Dampak Peningkatan Harga Beras Terhadap Tingkat Kesejahteraan Petani Pada Beberapa Strata Luas Lahan. Skripsi Departemen Sosial Ekonomi Pertanian Fakultas Pertanian Universitas Sumatera Utara. Medan.

Intriligator, M.D. 1978. Econometric Model. Techniques. and Applications. Prentice Hall Inc. New Jersey.

Kementerian Pertanian.2015. Peraturan Menteri Pertanian No. 03 Tahun 2015 tentang Pedoman Upaya Khusus (UPSUS) Peningkatan Produksi Padi, Jagung, dan Kedelai Melalui Program Perbaikan Jaringan Irigasi da Sarana Pendukungnya Tahun Anggaran 2015. Jakarta.

Koutsoyiannis. 1977. Theory of Econometrics: An Introductory Exposition of Econometric Methods. Second Edition. Macmillan Publishers Ltd. London.

Pindyck, R.S. and D.L. Rubinfeld. 1991. Econometrics Models and Economic Forecast. Third Edition. McGraw-Hill Inc. New York.

Poerwadarminta, W.J.S. 2003. Kamus Umum Bahasa Indonesia. Balai Pustaka. Jakarta.

Rizieq, R. 2010. Dampak Subsidi Pupuk Terhadap Kesejahteraan Petani. Jurnal Soca Vol. 10 (2) : 121 - 127. ISSN: 1411-7177.

Santoso,S. 2000. Buku Latihan SPSSStatistik Parametrik. Elex Media Komputindo.Jakarta.

Undang-Undang Republik Indonesia Nomor 11 Tahun 2019 Tentang Kesejahteraan Sosial. 